\title{
Access and Use of Agricultural Information in Africa: Conceptual Review
}

\author{
Adi Kelil $^{1} \quad$ Yohannes Girma $^{2} \quad$ Minas Hiruy $^{3}$ \\ 1. Department of Agricultural Economics, Jinka University, @Ethiopia \\ 2. Departement of Agricultural Economics, Injibara University, @Ethiopia \\ 3. Department of Rural Development and Agricultural extension, Debre markos University, @Ethiopia
}

\begin{abstract}
Agricultural production and productivity is greatly determined by the amount of information available to its stakeholders . Limited Agricultural information access is a key factor that has greatly limited agricultural advancement in Africa. Agricultural Researchers centers continue to generate new agricultural information from local to global levels but most of Small scale farmers in Africa limited to access relevant, reliable and up to date Agriculture information. This could be attributed to lack of farming practice and processing agricultural technologies. Hence, this paper is intended to review access and use of agricultural information in Africa. The result indicated that access and use of agricultural information is an imperative to make rational decision, reduce uncertainty, and enhance adoption of farm innovation and production. Accordingly, dissemination of agricultural information has indispensible role for rural dweller livelihood empowerment. Based on the review, the study recommends resolving the challenges which impede provision of agricultural information using combination of information provision channels with consideration of information quality to increase accessibility of agricultural information.
\end{abstract}

Keywords: Agricultural information, Access, use, Information source

DOI: $10.7176 / \mathrm{IKM} / 10-7-01$

Publication date:October $31^{\text {st }} 2020$

\section{Introduction}

Africa is the continent where the economy's backbone is agriculture and where the largest percentages of people are poor farmers. About two-thirds of the population in Africa, especially in sub-Saharan Africa and about $72 \%$ of those in East Africa are dependent on agriculture for their livelihoods (Adekunle et al., 2012). Agricultural information is the cornerstone of successful socio-economic development because it plays a key role in access to and use of agricultural information for agricultural inputs, market price, transportation systems of yield, environmental protection techniques and practices, new agricultural technologies, food processing and preservation (Mtega,2012).

The dissemination of agricultural Information is very crucial to agricultural productivity of farmers because it is only through this means that they can learn innovations which can improve their productivity (Sanusi, et.al, 2010). To enhance the production and productivity of agriculture, farmers should have access to well organized, need based, relevant information and proper agricultural information (Lawaliro et al., 2014). The use of information in agricultural sector is enhancing farm productivity in a numbers of ways. Providing information on weather trends, best practice in farming, timely access to market information helps farmer make correct decisions about what crops to plants and where to sell their product and buy inputs(Bachhav,2012).

Access to information is a vital tool for empowering individuals to make informed decisions and take prudent action for community development. Lack of access to relevant agricultural information by smallholder farmers' in developing countries cut across all subsectors of agriculture and different stages of agricultural production process (Okwu et. al, 2011). Insufficient information access, poor infrastructure, high access costs and illiteracy have contributed to poor production including agricultural production in rural areas (Odini, 2014).

In the rural areas of Africa lack of access to agricultural information, technologies and technical knowledge in agricultural farming practice was among the factors that responsible for low cash crop yield (Mahmood and Abbas, 2008). even if large body of agricultural knowledge that exists in research institutions, universities and public offices, only a small amount of agricultural information is accessible to rural farmers. Despite the agricultural technologies that have been generated through research, the impact of such technologies is yet to be felt in most households owing to inefficiency in communicating and sharing agricultural information and knowledge among smallholder farmers (Assefa, 2016). lack of agricultural information is largely attributed to the weak linkages between research, extension, libraries and farmers and thus these technologies have neither reached nor been adopted by their intended beneficiaries to improve their farming activities in developing countries (Benard et al., 2014).There is a positive relationship between the increased use of Agricultural information and agricultural development (Fawole, 2008).

The focus of this study is to review the access and use of agricultural information in Africa. Thus, the assessment of the information role, examining the challenges and identification of information sources was 
pertinent issues to this review.

This review is aimed at:

1. To assess the role agricultural information for smallholder farmers.

2 To examine challenges in accessing agricultural information among smallholder farmers

3. To identify sources of agricultural information used by smallholder farmers

\section{Methodology}

To set out to the objectives of this paper various related studies have been reviewed.

\section{Agricultural information: Definitions and Concepts}

The concept of information is very complex, it is evident in the various definition and attributes of the concept notwithstanding the fact that information is as old as man is, and that it affects and is affected by all aspects of human activities (Ukachi, 2011). Information is the fifth most important factor that interacts with other production factors (Muvezwa, 2006). Production factors, such as land, labor, capital, and managerial ability, can arguably be improved by relevant, reliable and useful information. The quality of information rests solidly on three pillars which are accuracy, timeliness and relevance. (Adereti et al., 2006) stated that accuracy implies that information is free from bias; timeliness means that recipients can get information when they need it, while relevance implies weather the piece of information specifically answers the users'

Agricultural information defined as various sets of messages that are relevant to agricultural production activities of farmers such as crop production and protection, livestock production and management, and natural resource production and conservation, marketing and processing (Kirimi, 2013). Agricultural information is defined as the data for decision-making and a resource that must be acquired and used in order to make an informed decision in agricultural system (Samuel, 2001). The dissemination of agricultural Information is very crucial to agricultural productivity of farmers because it is only through this means that they can learn innovations which can improve their productivity (Sanusi, et.al, 2010).

In the agriculture sector, smooth exchange on information is a key to the successful adoption of farm innovation needed for the agricultural development but due to lack of resources and poor infrastructure in many developing countries, a huge communication asymmetry exists between the latest agricultural knowledge and farmers (Baloch and Thapa, 2014). Access to Agricultural information is a critical dimension for agricultural technology choice and adoption. The decision to adopt innovations depends largely on access to agricultural information available to farmers (Meinzen, 2012)

\section{Results}

\subsection{The role of Agricultural information for smallholder farmers}

Agricultural information is imperative for decision-making and a resource that has to be acquired and used in order to make informed decisions. The process of decision making depends on the information that is available for the farmer. Information facilitates the farmer to be more rational and hence increase the decision making abilities (Asres, 2005). The decision making process in agriculture rests squarely on information available to farmers, Ranchers, entrepreneurs and policy makers. Thus, information can best be considered as a productive resource, potentially limiting and influencing the efficiency of production (Eswara, 2008). Information enables farmers to make informed decisions regarding production and marketing and managing their lives successfully to cope with everyday problems and to realize their opportunities (Jerome and Theresa, 2009).

Accessibility of Agricultural information enables the farmers to reduce the level of uncertainty and make rational decisions. Jerome and Theresa (2009) asserted that Farming (peasant) which is the major occupation of rural people is full of uncertainty, they are uncertain about the survival of their crops in the farm, fish in the fish pond or other agricultural products in the farmland, the information provider must be able to provide relevant information to the rural people which will help in alleviating their fear on the survival of their agricultural products. Information is an important resource for individual growth and survival. The progress of modern societies as well as individuals depends a great deal upon the provision of the right kind of information, in the right form and at the right time. That helps people make the right decision and reduce their uncertainties (Benardet al., 2014).

Accessibility of agricultural information have indispensible role for economic development of rural farmer in Africa. Availability of information in respect of facilities (loan) to help small and medium scale business is a Necessity as government are establishing micro-finance. Rural dwellers must be empower through information on what to do, how to do it and when to do it (Jerome and Theresa, 2009).

Agricultural Information is vital for farmer throughout their decision making process. Access to appropriate, timely and accurate information enables farmers to make better decisions about what to produce, when to produce and where to sell product than those who do not have such information (Ferris, 2005). Knowledge and information are important factors for accelerating agricultural development by increasing agricultural production and improving marketing and distribution (Oladele, 2006) 
These days, information has come to be very crucial commodity, and a cornerstone of almost every successful socio-economic development endeavors. Agricultural information interacts with and influences agricultural productivity in a variety of ways. It can help inform decisions regarding land, labour, livestock, capital and management. Agricultural productivity can arguably be improved by relevant, reliable and useful information and knowledge (Demiryurek et al., 2008).

\subsection{The challenges in accessing agricultural information among smallholder farmers}

Despite the agricultural technologies that have been generated through research in Africa, the impact of such technologies is yet to be felt in most households owing to inefficiency in communicating and sharing agricultural knowledge. There is a gap between agricultural development and available technologies for sustainable development. This means there is poor transfer of information and knowledge to agricultural stakeholders by information providers, research, and agricultural innovation centers (Odini, 2014)

Empirical studies conducted by various researchers identified various constraints which impede farmers in accessing agricultural information. According to (Benard, et.al. 2014) the study findings in Tanzania revealed that the barriers to accessing agricultural information were associated with lack of information services, inadequate number of extension agents, inadequate funds and lack of awareness of information sources

Most of the farmers in Africa lack access to modern processing technology and market information (Matovelo, 2008). Study conducted by (Daudu, et.al, 2009) on Agricultural information sources utilized by farmers pointed out some of the problems encountered by farmers in Nigeria in accessing agricultural information. These include financial problems, inadequacy of facilities and incomplete or irrelevant information.

A study conducted by (Assefa, 2016) on Access and utilization of agricultural information by smallholder coffee farmers in Ethiopia pointed out some of the problems encountered by farmers in accessing agricultural information; such as poor support of DAs in delivering information of extension services, Lack of access to irrigation scheme, low level of technology adoption, inadequate information sources, Long distance to institutions and high cost of ICTs tools. similarly, study conducted by (Tologbonse, et.al, 2008) on information need of rice farmers community in Niger state, the findings reveal that outdated information, language barrier, lack of awareness on existence of different information sources, lack of funds to acquire information and poor format of information carrier were the challenges facing farmers in accessing agricultural information by rice producer farmers.

Moreover, Matovelo (2008) in Tanzania and Austine et al. (2018) in Malawi-revealed that, lack of cooperation from fellow farmers in sharing agricultural information, language barriers, Poor information infrastructure, High illiteracy levels, low income, and high cost of ICTs are the barriers encountered by farmers in accessing Agricultural information.

Similarly, Odini (2014) study finding in Kenya and Igwe (2012) in Nigeria showed that the major constraints facing farmers in accessing information were Language barriers, Illiteracy, Geographical Distance, and Lack of Infrastructure.

\subsection{The sources of agricultural information used by smallholder farmers}

For any meaningful information to be provided, certain relevant information sources require to be consulted. It is only through such sources that information seekers can get information that is ideal for a meaningful decisionmaking leading to increase in productivity. The efficiency of technologies generated and disseminated depends on effective communication which is the key process of agricultural information dissemination from the appropriate agricultural information sources (Kalusopa, 2005).

Studies conducted by various authors identified various sources which preferred by farmers in accessing agricultural information. Lwoga(2011) had stated that, The major sources of information for farmers in Tanzania were predominantly local (neighbours, friends and family), followed by public extension services. Apart from radio and cell phones, advanced technologies (i.e. internet and e-mail) and printed materials were used at a low rate despite their existence in the communities.

Furthermore, studies conducted by Benard (2014) revealed that personal experience, family/parents and neighbors or friend were the most preferred sources of information, while internet, library and information centers and newspapers were not preferred sources of information. These imply that the farmers prefer interpersonal methods in receiving agricultural information, this probably because with interpersonal method farmers can easily share their experiences with each other so as to improve production.

The study conducted by Daudu (et al 2013) in Nigeria further showed that the main sources of information used by farmers in accessing agricultural information were Extension agents, Friends, Radio and Libraries. Furthermore, Dutta (2009) asserted that informal information network and extension agents were the most preferred and good options for finding reliable and quality information.

Therefore, in view of the fact that each farmer prefers certain information sources or channels over others, it is important to do a thorough study regarding the viability if information source before dissemination of 
agricultural information.

\section{Conclusions}

In agriculture, productivity is greatly determined by the amount of agricultural information available to its stakeholders. Access and use of relevant agricultural information is critical dimension to make informed decisions regarding production and managing their livelihood successfully to cope up with everyday problems and to realize their opportunities.

Access to relevant agricultural information is very useful to alleviate uncertainty and its Availability enables the farmers as the resolution of uncertainty. This is perhaps due to farmers are uncertain about the survival of their agricultural production in the farmland, the information provider must be able to provide relevant information to the rural people which will help in alleviating their fear on the survival of their agricultural products.

\section{Recommendation}

Based on the review made from different literatures, recommendations were given as follows.

The quality of information such as accuracy, timeliness and relevance ought to be considered before disseminating agricultural information so as to make viable decision and reduce uncertainty. It required resolving the challenges which impede provision of agricultural information using opportunities effectively to increase accessibility of agricultural information

The farmer uses a combination of the formal and informal source at different level and prefers certain agricultural information sources over others. Therefore, it is important to use various source of information and identification Farmer preference before selection of information source depend on the level of preference. It is an imperative to involve farmers in the design and development of agricultural information source to boost the Diffusion rate and use of agricultural information in the local communities.

Agricultural support services, Researchers, educators and extension agents should nurture on Mapping of suitable dissemination channel of information to influence farmers' decisions and adoption of information so that Farmers are more likely to be motivated on undertaking imperative decision and adopting improved technologies.

\section{REFRENCE}

Adekunle, A., Ellis-Jones, I. Ajibefun, R., Nyikal, S., Bangali, O., Fatunbi and Ange A., (2012). Agricultural Innovation in Sub- Saharan Africa: Experiences. From Multiple-Stakeholder Approaches. Proceedings of Forum for Agricultural Research in Africa. Accra, Ghana

Adereti, F.O.,Fapojuwo, O.E. and Onasanya, A.S.2006. Information Utilization on Cocoa production Techniques by Farmers in Oluyole Local Government area of Oyo State, Nigeria. European J. Soc. Sci., 3(1): 1-7.

Asres, E. (2005). Access and Utilization of Development Communication by Rural Women in Dire Dawa Administrative Council, Eastern Ethiopia. M.Sc. Thesis, Alemaya University, Ethiopia.

Assefa, M. (2016). Access to and utilization of agricultural information by smallholder coffee farmers in deder district, eastern harangue zone, Oromia national regional state. Thesis, haramaya University, Haramaya, Ethiopia.

Austine,P., George,T., and Winner D.(2018). Information needs and barriers of rural smallholder farmers in developing countries: A case study of rural smallholder farmers in Malawi. SAGE journal. Avialable at https://doi.org/10.1177/0266666918755222

Baloch, A. M., and Thapa, B. G. (2014). Agricultural extension in Balochistan, Pakistan: Date palm farmers' access and satisfaction. Journal of Mountain Science, v.11, n.4, p.1035-1048. 2014.

Bachhv, N.B. (2012). Information needs of the rural farmers: A study from Maharashtra, India; A survey, Library Philosophy and Practice, Available http://digitalcommons.unl.edu/cgi/viewcontent.cgi?article=2043\&context=libphilprac

Benard, R, and Dulle.F. (2014). Assessment of information needs of rice farmers in Tanzania; A case study of Kilombero District, Library Philosophy and Practice (e-journal), Spring 1-22

Daudu, S, Chado, S.S and Igbashal, A. A. (2009), Agricultural information sources utilized by farmers in Benue state, Nigeria, Publication Agriculture and Technology, Vol.5 (1),39-48. Available at http://patnsukjournal.net/Vol5No1/p5.pdf

Demiryürek, K. (2010). "Analysis of information systems and communication networks for organic and conventional hazelnut producers in the Samsun province of Turkey." Journal of Agricultural Systems.

Dutta, R. (2009). Information needs and information-seeking behavior in developing countries: A review of the research. The International Information \& Library Review, 41, 44-51.

Eswara, D. (2008).holistic view of agricultural information transfer systems. Proceed present at 74th ifla general conference and council available at http://www.ifla.org/IV/ifla74/index.htm

Fawole, O.P. (2008). "Pineapple farmers' information sources and usage in Nigeria", Bulgarian Journal of Agricultural Science, Vol. 14 No. 4, pp. 273-7, available at: www.agrojournal.org 
Ferris, S. (2005). Developing market information services in Eastern Africa: the food net experience, local, national and regional market information services. International Institute of Tropical (IITA), Ibadan Nigeria.

Igwe,H.(2012). "Use of library and information sources". Offa: Wunmi Commercial Press and Correctman printing production, Pp. 43-57.

Jerome,I and Theresa, A.(2009). Information as an effective tool in rural development. International Journal of Library and Information Science Vol. 1(3) pp. 022-028. Available online http://www.academicjournals.org/ijlis

Kalusopa, T. (2005). "The challenges of utilizing information communication technologies (ICTs) for the small-scale farmers in Zambia", Library Hi Tech, Vol. 23 Issue: 3, pp.414-424.

Kirimi, P. M. (2013). Assessment of women smallholder sorghum farmers access to Agricultural information in Mwingi central district, Kitui county, Kenya. Dissertation for Award Degree of MSc at Nairobi University, Kenya. 59pp.

LawalIro, S., Boadi, B.Y., Oladokun, O., \& Kalusopa, T. ( 2014). The Generation and Dissemination of Agricultural Information to Farmers in Nigeria.

Lwoga,T.E., Stilwell, C.\& Ngulube, P. (2011). "Access and use of agricultural information and knowledge in Tanzania", Library Review, Vol. 60 No. 5, pp. 383-395. https://doi.org

Mahmood, M.A. \& Abbas, M. (2008). Dissemination of Wheat Maize Seed and Fertilizer in North Tanzania. Indian Journal of Agricultural Economics 48(1):1-12.

Matovelo, D.S. (2008). Enhancing farmer's access to and use of agriculture information for empowerment and improve livelihoods: a case of Morogoro region. Thesis presented at University of Dar es salaam as the requirement of Doctor of Philosophy

Meinzen, D, R. (2012). Property Rights, Collective Action and Technologies for Natural Resource Management. CAPRi Policy Brief. Washington, DC. Available at (http://www.cgiar.org/capri/pdf/polbrief_01.pdf, Accessed march 4, 2020).

Mtega, Wulystan P. (2012). Access to and usage of information among rural Communities: a cases study of Kilosa District Morogoro Region in Tanzania. Volume 7, No.1, the Canadian journal of Library an information Practice and Research.

Muvezwa, J. (2006). The Fifth factor Africa Capacity Building. Harare, Zimbabwe

Odini, S. (2014).Access to and Use of Agricultural Information by Small Scale Women Farmers In Support of Efforts to Attain Food Security in Vihiga County, Kenya: Journal of Emerging Trends in Economics and Management Sciences(JETEMS) 5(2):100-107.

Odini, S. (2014). Access to and Use of Agricultural Information by Small Scale Women Farmers In Support of Efforts to Attain Food Security in Vihiga County, Kenya. Journal of Emerging Trends in Economics and Management Sciences (JETEMS) 5(2):80-86

Okwu, O.J \& Iorkaa, T.I. (2011). An Assessment of Farmers' Use of New Information and Communication Technologies as Sources of Agricultural Information in Ushongo Local Government Area, Benue State, Nigeria. Journal of Sustainable Development in Africa, 13(2).

Oladele,O.I. (2006). Multilinguality of Farm Broadcast and Agricultural Information Access in Nigeria.Nordic Journal of African Studies 15(2): 199-205

Samuel, G. S. (2001). The Development of Integrated management Information Systems for Agricultural Extension Institutions of Developing Countries: The Case of Oromia Agricultural Development Bureau of Ethiopia. Aachen, Shaker, Ethiopia.

Sanusi, M. A., Petu-Ibikunle, A. M., \& Mshelia, C. M. (2010). The influence of Information and communication technology (ICT) on the dissemination of agricultural information among urban farmers in the Northern Guinea Savannah zone of Nigeria. African Scientists, 11(2):135-145.

Tologbonse, D, Fashola, O, \& Obadiah, M. (2008). Policy Issues in Meeting Rice Farmers Agricultural Information Needs in Niger State. Journal of Agricultural Extension Vol. 12 (2)

Ukachi, N.B. (2011). Information need, sources and information seeking behaviour of rural women in Badagry.University of Lagos, Information Trends. Vols. 4 \& 5. Available at http://www.unilag.edu.ng. 